\section{STRUCTURE, CONDUCT AND \\ PERFORMANCE OF THE RICE MILLING INDUSTRY OF SRI LANKA: EVIDENCE FROM SELECTED CASES}

Asanka Wijesinghe

Jeevika Weerahewa
Sri Lanka Journal of

Economic Research

Volume 4 (2) June 2017 SLJER.04.02.04: pp. 71- 90

Sri Lanka Forum of

University Economists

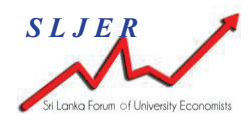

\title{
Abstract
}

The rice milling industry in Sri Lanka is alleged to be characterised by imperfect competition and excessive profits. The purpose of this study was to examine the structure, conduct and performance of the rice milling industry of Sri Lanka. The structure of the industry was examined using concentration ratio and HirschmanHerfindahl Index (H index). The conduct of the industry was examined using a Hedonic price analysis. In order to evaluate the performance of the industry, the technical efficiency of the rice millers was estimated. Marketing margins over time and across different groups of millers were also examined to test whether there was an increase in the margins between retail prices of rice and farm-gate prices of paddy as an alternative indicator to ascertain industry performance. The results of the analysis indicated that the top four firms in the sample occupied $6.30 \%$ of the market share, implying that the rice milling industry of Sri Lanka was atomistically competitive. The calculated $H$ index of 30 also suggests that the market was competitive. Contrary to popular belief, the results of the Hedonic price analysis indicated that consumers were indifferent among brands and that none of the established brands had a significant effect on rice prices. The results of the input orientated Data Envelope Approach indicated that the mean technical efficiency of the millers in the sample was over $90 \%$ and there is no statistically significant difference in the technical efficiencies of large scale millers who possess modern machineries and that of the rest. Furthermore, there is no evidence to conclude that millers with superior milling equipment have excessive margins.

Key Words: Structure, Conduct, Performance, Rice Milling, Sri Lanka

\section{Asanka Wijesinghe}

Department of Agricultural, Environmental and Development Economics, The Ohio State University, Columbus, US 43202

Telephone: +1 701793 5548, Email: wijesinghe.3@osu.edu

\section{Jeevika Weerahewa}

Department of Agricultural Economics and Business Management, Faculty of Agriculture, University of Peradeniya, Peradeniya, Sri Lanka

Telephone: +94 7739821 61, Email: jeevikaw@pdn.ac.lk 


\section{INTRODUCTION}

An efficient agricultural commodity market is vital for developing countries which are characterised by the presence of poor farm producers and less affluent urban consumers. Inefficiencies in markets have widespread ramifications on both consumers' and producers' welfare. Governments of many developing countries have been using various instruments to ensure reasonable prices for farm-producers, affordable prices for poor urban consumers, to promote price stability and to avoid the formation of monopolies. Sri Lanka is not an exception. Seasonal price depressions and the escalation of consumer price of rice in off-seasons have been cited as chronic characteristics of the paddy and rice markets of Sri Lanka. Successive governments that came to power in Sri Lanka have been using a multitude of policies ranging from import restrictions to government procurement at guaranteed prices at farm level to address issues in marketing rice. At present, the rice marketing system is characterised by an interaction between state regulatory activities and private sector marketing activities.

Despite extensive interventions by the state, the rice milling industry in Sri Lanka is alleged to be concentrated and to be generating excessive profits. Technologically superior large scale millers with established brands are blamed for alleged anticompetitive actions such as price discrimination, branding, exercising of lobbying power and erection of entry barriers. However, scientific studies conducted on this issue had concluded otherwise. The World Bank (1996), Rafeek et al. (undated), Wijesuriya and Priyadarshana (2013), Senanayake and Premaratne (2016), and Senaratne et al. (2017) did not reveal any anti-competitive behavior in the rice milling industry in Sri Lanka. Inspired by the existing scholarly debate and the importance of policy implications, this study analyses the structure, conduct and performance (SCP) of the rice milling industry of Sri Lanka using some alternative analytical tools and data.

The paper is organised as follows. The second section chronicles the evolution of the rice milling industry under different policy regimes. The third section presents the SCP paradigm and the fourth section presents the empirical approach. The results of the analysis with respect to SCP are presented in the fifth section. The paper ends with a summary and conclusions.

\section{Evolution of Rice Milling Industry of Sri Lanka}

The evolution of rice milling industry has been extensively influenced by periodical policy changes of governments. Athukorala and Kelegama (1998), Gunawardana and Somaratne (2000), Weerahewa (2004), Karunagoda et al. (2010) and Weerahewa et al. (2016) provide good reviews of the evolution of agricultural policy framework. The policy regimes in Sri Lanka have been generally categorised by these authors as (i) free 
market policies since independence up to 1959 , (ii) import substituting industrialisation during 1960-1977, and (iii) export oriented liberalisation since 1977. However, in this study, policy regimes are presented as 1930-1971, 1972-1977, 1978-2004 and 20052016 , in order to better describe the evolution of the rice milling industry.

\section{Rice Milling Industry before $1972^{1}$}

It is evident that Sri Lanka was self-sufficient in rice during the times that kings ruled the country. However, by 1930s, the domestic production was not sufficient to meet the demand and rice was mainly imported. This situation accelerated the opening up of the Dry Zone for rice cultivation which started in 1935 with the Land Development Ordinance. The state agencies were involved in purchasing paddy from domestic producers under a Guaranteed Price Scheme (GPS), milling, importing and distributing of rice. From 1942, rice was distributed through the Rice Ration Scheme (RRS) which facilitated an equitable distribution.

During this period, entry barriers to the rice milling industry have not been reported and it can be inferred that the private sector also involved in milling the remaining domestic paddy production. The pricing behavior of the government affected both supply and demand sides via GPS and RRS respectively. The government was the dominant stakeholder which maintained the low consumer price of rice while assuring a higher producer price. Private sector performed in a competitive market environment and price discrimination or parallel black markets were not reported during this period.

\section{Rice Milling Industry during 1972-1977 under the Paddy Marketing Board Monopoly}

Sri Lankan economy was faced with external shocks of world oil crisis, and the world food and fertiliser shortages during this period (Indraratna, 2009). The government adopted a policy of food self-sufficiency under increased government intervention in domestic factor and product markets (Gunawardana and Somaratne, 2000). There were high tariffs for all imports except essential food items and Sri Lanka became a highly restricted and regulated economy in this period (Indraratna, 2009).

The government established Paddy Marketing Board (PMB) the state parastatal in 1971. The PMB Act of 1971 granted the sole authority in rice milling to the PMB (Gunawardana and Somaratne, 2000). The only legal space the millers in the private sector had was to function as registered millers who milled paddy purchased by the

\footnotetext{
${ }^{1}$ The basis for this demarcation is that, in 1972, Sri Lanka economy embraced a command economy under the influence of socialism and rice marketing system was taken under the state monopoly. Before 1972 country had a market economy at least in its restricted features.
} 
PMB. However the market share of PMB over time declined gradually as the guaranteed price was not attractive (Yoshimura et al. 1975). Thus the government failed to procure enough rice for RSS requirements and was thus compelled to adopt measures such as prohibiting the storage and transportation of rice in bulk in order to increase the quantity of procurement. Yoshimura et al. (1975) noted the presence of a functioning illegal rice marketing channel in this period. Gunawardana and Somaratne (2000) revealed an emergence a parallel black market with market power.

\section{Rice Milling Industry in Post Liberalised Period I: 1977 to 2004}

The rice milling industry entered into a new phase under the market economy introduced in 1977. In 1978, the PMB Act was amended and the private sector was allowed to market rice based on competition removing the state imposed entry barriers. In order to safeguard consumer interests, importation of rice was allowed when their prices in domestic markets increased sharply due to bad harvests, speculation, or other disturbances $^{2}$. In 1988, private sector was allowed to import rice under a strict quota system and in 1990 a system of bonded warehouse storage was initiated. The Food Commissioner, under contractual agreement, provided license to three offshore privatesector companies to import and store rice as a buffer stock for later sale (Food and Feed Grains Institute, 1992).

As the state sector gradually contracted its market share after economic liberalisation, private sector occupied a large market share in post liberalised rice milling industry. The role of the PMB had been reduced to 'the buyer of last resort': supporting the floor prices when market prices fall below the floor prices, particularly during harvests (Gunawardana and Quilkey, 1987). In the 1990s, PMB storage facilities in rice producing areas were handed over to private investors and the storage capacity of the PMB was further weakened. According to the Central Bank of Sri Lanka, state sector market share reduced to $10 \%$ by 1995 .

In this post liberalisation period private sector rice milling industry was organised into a major agro-based industry in horizontal and vertical space. The purchasing and collection of paddy from farmers were mainly handled by the millers and assembly traders called collectors. Assemblers and middlemen, who handle few stocks of paddy, did not have large storage facilities and the wholesalers, who handle a comparatively large portion, possessed the majority of stocks and storage facilities. The rice mills were of two types: custom and commercial rice mills. A survey conducted by the Institute of Post-harvest Technology (IPHT) revealed that all the custom mills and 95 percent of the

\footnotetext{
${ }^{2}$ In this period rice imports were used for price stabilisation purposes.
} 
commercial mills are owned by the private sector. The remaining 5 percent of the commercial rice mills belong to the Cooperatives (IPHT, 2003).

\section{Rice Milling Industry in Post Liberalised Period II: 2005-2016}

The Ten-Year Horizon Development Framework (THDF) ${ }^{3}$ 2006-2016 embodies a strategy of restraining the open-economic framework set in motion after 1977 by refocusing attention on the agriculture sector and import substitution, stronger government intervention in the production system, reinstatement of subsidies, and active perusal of trade policies. The government revived the operations of PMB in 2007 and allowed private sector to purchase paddy under competitive prices. Private millers were given credit facilities to modernise their mills as technology was asymmetrically distributed in the industry. This phenomenon and the presence of large scale millers were major contributors to the argument that these large scale millers with modern machineries had market power.

The government imposed a priced ceiling for the retail and wholesale prices of commonly consumed locally produced rice types in 2008 (Central Bank of Sri Lanka, 2008). Imported and high quality rice types were not subjected to price ceilings. Government continued to purchase paddy under the certified price of Rs $32 / \mathrm{kg}$ of short grain paddy and Rs $28 / \mathrm{kg}$ of long grain paddy. In 2015, newly elected national unity government increased the certified prices of paddy up to Rs $50 / \mathrm{kg}$ of short grain paddy and up to Rs $45 / \mathrm{kg}$ of long grain paddy.

The government continued to impose import taxes in harvesting periods and to reduce them in periods with peak demand. For example, in April 2014 many import taxes were replaced with $5 \mathrm{Rs} / \mathrm{kg}$ levy to reduce the domestic rice price while in January 2015 the levy on the importation of rice was increased to Rs $20 / \mathrm{kg}$ from Rs $1 / \mathrm{kg}$ for a period of four months as it was the harvesting season (Central Bank, 2013, 2014 and 2016).

\section{Structure Conduct and Performance Paradigm}

SCP model (Bain, 1951) is credited as one of the earliest methods of analysing the organisation of an industry ${ }^{4}$. The SCP paradigm dominated empirical analyses of industrial organisations between the 1950s and early 1980s and had significant influence on policymaking, especially in the area of antitrust. Even though there was not

\footnotetext{
${ }^{3}$ After 2005 with the political changes THDF is the main reference document for all national planning (Atapattu, 2011).

${ }^{4}$ The more modern New Empirical Industrial Organisation (NEIO) approach employs the price-cost margin (PCM) models and criticises the SCP for having weak econometric foundation.
} 
much enthusiasm for economists in developed economies to carry out empirical studies using SCP after the 1980s, much of the literature on developing country experiences continues to be based on the SCP paradigm. This is due to the plausibility of the SCP paradigm in dealing with data available in developing countries.

The SCP paradigm postulates causal relationships between the structure of the market, conduct of the firms in the market and conduct of the firms and their economic performance. According to Schmalensee (1989) variables used to explain structure are classified into two categories. The first category is the intrinsic structural variables: those determined by the nature of products and the available production and marketing technologies. The second is the derived structural variables determined by firms and government such as barriers of entry, seller and buyer concentration and product differentiation. Buyer concentration is an important factor that determines market power in agricultural commodity processing industries. The greater the dominant firm's ${ }^{5}$ market share at its profit-maximising output, the smaller the demand elasticity it will be facing and the greater its market power (Landes and Posner, 1981).

Conduct is the behavior of firms which can be competitive or collusive, as well as their pricing, research and development activities, advertising, production, choice of technology and predation.

Performance is social efficiency which is mainly defined by the extent of market power. According to economic theory one ought to define a firm with substantial market power as one that is able to enhance its profits by raising prices substantially above marginal cost for a substantial volume of sales (Landes and Posner, 1981). Marketing margins are useful evidence of market power. They give an indication of the performance of a particular industry (Tomek and Robinson, 1990). For instance, Gordon and Hazledine (1996) have argued and shown in their study that greater market power is likely to manifest in larger marketing margins than would otherwise be the case.

\section{THE EMPIRICAL APPROACH}

\section{Measurement of Structure of the Rice Milling Industry}

The structure of the rice milling industry of Sri Lanka was analysed using concentration ratio, and Hirschman-Herfindahl Index ( $\mathrm{H}$ index). They were calculated as per equations (1) and (2).

\footnotetext{
${ }^{5} \mathrm{~A}$ 'dominant firm' in industrial organisation theory is generally a single large seller facing many, small, price-taking rivals, while a 'monopoly' is the only seller of some good or service (Schmalensee, 1985).
} 


$$
C R=\sum_{i=1}^{m} P_{i} ; m \geq 1 ; 0 \leq C R \geq 1
$$

where $C R$ is the concentration ratio, $\mathrm{P}_{\mathrm{i}}$ denotes the share of the $\mathrm{i}^{\text {th }}$ firm arranged in descending order and $m$ is the number of largest firms under consideration. This study considers it as four.

$$
H=\sum_{i=1}^{n}\left(P_{i}\right)^{2} ; P_{i}=\frac{q_{i}}{Q} ; i=1,2,3 \ldots N
$$

where $\mathrm{H}$ is the $\mathrm{H}$ index, $\mathrm{q}_{\mathrm{i}}$ is the output of the $\mathrm{i}^{\text {th }}$ firm arranged in descending order and $\mathrm{Q}$ is the total output of all the firms in the industry which is denoted by $\mathrm{n}$. Industrial classification of Bain (1959) was used to identify the prevailing structure of the rice milling industry. Accordingly, if the top four firms controlled 75 to 100 percent of the business of a product, it was considered as a highly concentrated oligopoly, while for a market share of 50 to 75 percent it was recorded as a moderately concentrated oligopoly. For 25 to 50 per cent it was called a slightly concentrated oligopoly and for less than 25 per cent of the business, it was referred as atomistically competitive. Threshold values for $\mathrm{H}$ index given by Horizontal Merger Guidelines of the Department of Justice and the Federal Trade Commission, USA was used for interpretations of $\mathrm{H}$ values obtained as follows.

i) Competitive Markets: $\mathrm{H}$ index below 1500

ii) Moderately Concentrated Markets: $\mathrm{H}$ index between 1500 and 2500

iii) Highly Concentrated Markets: $\mathrm{H}$ index above 2500

In order to compute concentration ratio and $\mathrm{H}$-index using the above formula, quantities sold by all firms in the industry are required. However, the annual industry surveys conducted by the Department of Census and Statistics provides aggregated data on grain mill products, and disaggregated data on the rice milling industry are not available in the final reports of the Annual Survey of Industries. Therefore, concentration ratio and H-index were computed using data gathered by the rice milling survey of 2006 of the Hector Kobbekaduwa Agrarian Research and Training Institute (HARTI). It is a postal survey of 1,727 millers from all the districts of the country. The capacity of the mill was considered as the size of the firm and the quantity supplied to the market. One of the caveats of this dataset is that there is no guarantee that all the large millers, which are few in number, had responded to the survey. 


\section{Measurement of Conduct of the Rice Milling Industry}

The conduct of the milling industry was analysed according to the product differentiation in terms of different rice types, their attributes and the availability of brands. Hedonic price analysis was performed to find the implicit prices paid for different quality attributes of rice and available brands by the consumers. Following previous studies in literature (Goodwin et al., 1996; Mhlanga, 2010 and Walisingha and Gunaratne, 2012) color, size of grain, impurities, rate of breakage, type of processing, packaging, place of the market and brands were selected as attributes of rice. Equation (3) specifies the model.

$\mathrm{P}_{R}=\beta_{0}+\beta_{1} x_{1}+\beta_{2} x_{2}+\ldots+\beta_{8} x_{8}+\varepsilon$

where $P_{R}$ denotes the observed market price of rice and the vector of $\mathrm{X}$ are the explanatory variables. They are presented in Table 1 .

In order to do the hedonic analysis, primary data were collected from retailers in Negombo in Gampaha district of Sri Lanka. Data was collected from four retail shops, two supermarkets and one cooperative shop. All rice types available in those shops were inspected for the quality characteristics considered which were recorded thereafter.

\section{Measurement of Performance of the Rice Milling Industry}

In order to evaluate the performance of the rice milling industry of Sri Lanka, the technical efficiency of rice millers in a representative industry segment and the marketing margin of rice price were computed. Data Envelopment Analysis (DEA), a non-parametric frontier method, is applied in this study to estimate the technical efficiency of the rice millers. Technical efficiencies were computed under two assumptions; (i) Constant returns to scale (CRS) following Charnes, Cooper and Rhodes (1978) and (ii) Variable Returns to Scale (VRS) following Banker, Charnes and Cooper (1984).

For the DEA estimation the output variable was the monthly processed rice output of the mill. Input variables were electricity use, paddy input, labor use and milling capacity as a proxy to capital. Data for these variables was gathered from a primary survey conducted using a structured questionnaire in July in 2012 from millers in Gampaha district. Gampaha was selected as it is a major rice processing district in Sri Lanka especially around Maradagahamula. 
Table 1: Quality Attributes and Base Categories for Implicit Price Estimations of the Quality Attributes of the Rice Types for the Analysis of Rice Product Differentiation

\begin{tabular}{|c|c|c|}
\hline Grain Characteristics & Survey Ranking & Base Category \\
\hline Type of rice & $\begin{array}{l}\text { Parboiled } \\
\text { Raw }\end{array}$ & Parboiled rice \\
\hline Brand & $\begin{array}{l}\text { No brand } \\
\text { Brand } 1 \\
\text { Brand } 2 \\
\text { Brand } 3 \\
\text { Others }\end{array}$ & No brand \\
\hline Grain size & $\begin{array}{l}\text { Short grain } \\
\text { Long bold grain } \\
\text { Long thin grain }\end{array}$ & Short grain \\
\hline Color & $\begin{array}{l}\text { White } \\
\text { Moderately yellow } \\
\text { Yellow } \\
\text { Moderately red } \\
\text { Red }\end{array}$ & Moderately yellow \\
\hline Impurities & $\begin{array}{l}\text { Prsence } \\
\text { Nil }\end{array}$ & Impurities-Nil \\
\hline Rate of breakage & $\begin{array}{l}\text { Very low rate of breakage } \\
\text { Low rate of breakage } \\
\text { Moderate rate of breakage } \\
\text { High rate of breakage } \\
\text { Very high rate of breakage }\end{array}$ & Very low broken rice \\
\hline Location of the market & $\begin{array}{l}\text { Supermarket } \\
\text { Retail shops } \\
\text { Cooperative shop }\end{array}$ & Retail shops \\
\hline Easiness of carrying & $\begin{array}{l}\text { Having small packs only } \\
\text { conventional packages }\end{array}$ & Unpackaged \\
\hline
\end{tabular}


As an alternative measure of performance, marketing margins were computed. First, using the HARTI survey data, farm gate-wholesale marketing margin was calculated by deducting the purchased price of paddy equivalent for one $\mathrm{kg}$ of rice from the prevailed market price that millers sold one $\mathrm{kg}$ of rice for each firm using the following formula.

$$
\mathrm{MM}=\mathrm{P}_{\text {rice }}-\mathrm{P}_{\text {paddy }}
$$

where $M M$ is farm gate-wholesale marketing margin, $P_{R}$ is the price of rice $(\mathrm{Rs} / \mathrm{kg})$ and $\mathrm{P}_{\mathrm{P}}$ is the price of paddy equivalent for one $\mathrm{kg}$ of rice. In order to test the hypothesis that large scale millers have higher gross marketing margin, marketing margins between two groups of millers are compared by unpaired t-tests. Further marketing margins are compared according to the availability of dryers, elevators and color separators which are the sophisticated machinery available in the industry.

The farm gate-wholesale, farm gate-retail and retail-wholesale margins were analysed in real terms for the 1991-2011 period. Nominal price data were deflated using wholesale price index. The dependent variables were regressed with time as the sole independent variable.

The regression equation specified is shown below.

$$
Y_{t}=\beta_{0}+\beta_{1} t+u_{t}
$$

where $Y_{t}$ is the dependent variable (marketing margins, wholesale price, retail price of rice and producer price of paddy), $\beta_{0}$ is the intercept, $\beta_{l}$ is the regression coefficient, $t$ donates years which takes values $1,2 \ldots T$ and $u_{t}$ is disturbance term for the year $t$.

Annual producer prices of paddy and market prices of rice were obtained from the Central Bank of Sri Lanka and the Food and Agriculture Organization to estimate equation (5).

\section{RESULTS AND DISCUSSION}

\section{Structure of the Rice Milling Industry}

The calculated concentration ratio of the top four firms in the industry in 2006 was 0.063 implying that the largest 4 firms had control over $6.3 \%$ of the industry. Hence the rice milling industry of Sri Lanka was found to be atomistically competitive in 2006 according to Bain's classification (1959). The calculated H index for the industry was 30. It is far below the Horizontal Merger Guidelines threshold of 1500 for a market to be considered as concentrated market. The analysis conducted at district level revealed that the major paddy producing districts of Sri Lanka, i.e., Anuradhapura, Polonnaruwa, Ampara, Kurunegala and Hambantota, do not deviate from the atomistically 
competitive condition except for Kurunegala district. In Kurunegala district the industry was characterised by a slight oligopsony (Table 2).

Table 2: Market Concentration and H Index for Major Paddy Producing and Rice Processing Districts

\begin{tabular}{lcc}
\hline \multicolumn{1}{c}{ District } & $\begin{array}{c}\text { Concentration Ratio } \\
(\mathrm{CR})\end{array}$ & $\begin{array}{c}\text { Hirschman-Herfindahl Index } \\
(\text { H index })\end{array}$ \\
\hline Gampaha & 0.191 & 190 \\
Anuradhapura & 0.185 & 210 \\
Polonnaruwa & 0.226 & 240 \\
Ampara & 0.140 & 180 \\
Kurunegala & 0.412 & 610 \\
Hambantota & 0.209 & 290 \\
\hline
\end{tabular}

\section{Conduct of the Rice Milling Industry}

The hedonic price model was estimated in linear form and the results are presented in Table 3. The results show that consumer was indifferent across brands in the particular market segment. None of the established brands had a significant effect on rice prices. According to Kohls and Uhl (1996) in a competitive market, buyers do not have a preference for one seller's product over another's and hence rice milling industry can be considered as competitive.

The differences in rice prices are due to grain size, colour of rice, breakages and packaging. The results indicate that consumers are willing to pay higher implicit prices for long thin grain than that for short grain and a lower implicit price for long bold grain than that for short grain. Packaged rice fetches a higher price and broken rice fetches a lower price. Consumers prefer to pay a higher price for red or white rice compared to yellow rice.

Two key implications are visible in the above results. On one hand, they indicate that higher rice prices are associated in instances where production costs are higher. On the other hand, there is no significant difference across the prices of different brands when controlled for quality characteristics. Therefore it is clear that the degree of product differentiation had not caused any market imperfection leading to building up of market power in the rice market. This implies that established brands cannot be considered as significant entry barriers as consumers were indifferent between brands. 
Table 3: Estimates of Linear Hedonic Model

\begin{tabular}{|c|c|c|c|c|c|}
\hline $\begin{array}{c}\text { Base Category } \\
\text { of the Dummy } \\
\text { Variables }\end{array}$ & Explanatory Variable & Coefficient & $\begin{array}{l}\text { Standard } \\
\text { Error }\end{array}$ & t Ratio & $\begin{array}{c}\mathrm{p} \\
\text { Value }\end{array}$ \\
\hline & Constant & 81.072 & 8.642 & 9.38 & 0 \\
\hline Parboiled rice & Raw & -10.327 & 9.83 & -1.05 & 0.297 \\
\hline \multirow[t]{4}{*}{ No brand } & Brand 1 & -18.669 & 12.561 & -1.49 & 0.142 \\
\hline & Brand 2 & -34.2 & 26.911 & -1.28 & 0.204 \\
\hline & Brand 3 & 3.641 & 16.754 & 0.22 & 0.829 \\
\hline & Other brands & 11.518 & 10.461 & 1.1 & 0.275 \\
\hline \multirow[t]{2}{*}{ Short grain } & Long-bold grain & -21.074 & 8.263 & $-2.55 * *$ & 0.013 \\
\hline & Long-thin grain & 73.811 & 10.98 & $6.72 * * *$ & 0 \\
\hline \multirow{3}{*}{$\begin{array}{l}\text { Moderately } \\
\text { yellow }\end{array}$} & White & 24.186 & 10.289 & $2.35 * *$ & 0.022 \\
\hline & Moderately red & 21.543 & 12.778 & $1.69 *$ & 0.096 \\
\hline & Red & -7.089 & 14.048 & -0.5 & 0.615 \\
\hline Impurities-Nil & Presence & 9.468 & 10.199 & 0.93 & 0.357 \\
\hline \multirow{3}{*}{$\begin{array}{l}\text { Very low } \\
\text { broken rice }\end{array}$} & Low broken rice & -18.586 & 13.594 & -1.37 & 0.176 \\
\hline & $\begin{array}{l}\text { Moderately broken } \\
\text { rice }\end{array}$ & -37.037 & 13.889 & $-\overline{2.67 * * *}$ & 0.01 \\
\hline & Highly broken rice & -24.818 & 19.153 & -1.3 & 0.199 \\
\hline \multirow[t]{2}{*}{ Retail shops } & Supermarket & 1.944 & 12.329 & 0.16 & 0.875 \\
\hline & Cooperative shops & 2.863 & 1.656 & -0.25 & 0.807 \\
\hline Unpackaged & Packaged & 31.842 & 16.353 & $1.95 *$ & 0.056 \\
\hline
\end{tabular}

* Significant at 10 percent probability.

** Significant at 5 percent probability level.

***Significant at 1 percent probability level.

$\mathrm{R}$ squared $=0.811$.

Adjusted R squared $=0.764$. 


\section{Performance of the Rice Milling Industry}

Efficiency measures of the input orientated DEA approach are given in Table 4. Under the assumption of CRS technology Decision Making Units that are lying on the ray of the linear programming model are considered as efficient. The mean $\mathrm{TE}_{\mathrm{CRS}}$ among rice millers was found to be 0.935 . The mean $\mathrm{TE}_{\mathrm{VRS}}$ technical efficiency and Scale efficiency were found to be 0.963 and 0.971 respectively. The efficiency of the least efficient firms was above 0.800 in all three scenarios. Accordingly the space for the increase in reducing input level at the given output is very less in the particular industry segment surveyed.

Table 4: Descriptive Statistics for Efficiency Measures in Input Orientated DEA

\begin{tabular}{lcccccc}
\hline \multicolumn{1}{c}{$\begin{array}{c}\text { Efficiency } \\
\text { Criteria }\end{array}$} & Mean & $\begin{array}{c}\text { Standard } \\
\text { Deviation }\end{array}$ & $\begin{array}{c}\text { Standard } \\
\text { Error }\end{array}$ & $\begin{array}{c}\text { Coefficient } \\
\text { of Variation }\end{array}$ & Minimum & Maximum \\
\hline $\mathrm{TE}_{\mathrm{CRS}}$ & 0.935 & 0.052 & 0.007 & 5.560 & 0.808 & 1.000 \\
$\mathrm{TE}_{\mathrm{VRS}}$ & 0.963 & 0.043 & 0.005 & 4.490 & 0.815 & 1.000 \\
$\begin{array}{l}\text { Scale } \\
\text { efficiency }\end{array}$ & 0.971 & 0.037 & 0.005 & 3.800 & 0.833 & 1.000 \\
$\left(\mathrm{TE}_{\mathrm{CRS}} / \mathrm{TE}\right.$ & & & & & & \\
\hline
\end{tabular}

Table 5: Mean Comparisons for $\mathrm{TE}_{\mathrm{VRS}}$ Scores in Input Orientated DEA

\begin{tabular}{|c|c|c|}
\hline Category & Mean $\mathrm{TE}_{\mathrm{VRS}}$ Score & Unpaired t Statistic \\
\hline (a) Millers with monthly output $\leq 50$ & 0.963 & \multirow{2}{*}{$\begin{array}{l}0.03 \\
(\text { Between (a) and (b)) }\end{array}$} \\
\hline (b) Millers with monthly output $\geq 50$ & 0.962 & \\
\hline (c) Millers without dryers & 0.965 & \multirow{2}{*}{$\begin{array}{l}0.4 \\
(\text { Between }(c) \text { and }(d))\end{array}$} \\
\hline (d) Millers with dryers & 0.96 & \\
\hline (e) Millers without elevators & 0.966 & \multirow{2}{*}{$\begin{array}{l}0.78 \\
(\text { Between (e) and (f)) }\end{array}$} \\
\hline (f) Millers with elevators & 0.957 & \\
\hline (g) Millers without color separators & 0.962 & \multirow{2}{*}{$\begin{array}{l}-0.54 \\
(\text { Between }(\mathrm{g}) \text { and }(\mathrm{h}))\end{array}$} \\
\hline (h) Millers with color separators & 0.973 & \\
\hline
\end{tabular}

According to Table 5, the large scale millers with monthly outputs higher than 50 metric tons and millers who possess modern machinery are not in a superior position than 
others in terms of pure technical efficiency. Therefore the hypothesis that large scale millers and millers who possess modern machinery are more technically efficient than others is rejected.

The results of the unpaired tests revealed that large scale millers do not have a comparative advantage over small scale millers in terms of marketing margin. Therefore the hypothesis that large scale millers have higher marketing margin as they alter producer prices and consumer prices using their market power is not accepted. Though the marketing margin of large scale millers was apparently higher for all types of rice than that of small scale millers the difference was not statistically significant. Similarly difference of mean marketing margins between two groups of millers for samba and nadu types ${ }^{6}$ were not significantly different (Table 6). Therefore the hypothesis that the large scale rice millers perform better than small scale millers in the rice milling industry was also not accepted.

Table 6: Marketing Margin and Scale of Production

\begin{tabular}{|c|c|c|}
\hline Category & $\begin{array}{l}\text { Mean Gross Marketing } \\
\text { Margin }\end{array}$ & Unpaired t Statistic \\
\hline (a) Millers with monthly output $\leq 50$ & 7.31(Average) & \multirow{2}{*}{$\begin{array}{l}-0.44 \\
(\text { Between (a) and (b)) }\end{array}$} \\
\hline (b) Millers with monthly output $\geq 50$ & 7.81(Average) & \\
\hline (c) Millers with monthly output $\leq 50$ & 7.67(samba type) & \multirow{2}{*}{$\begin{array}{l}0.69 \\
(\text { Between }(c) \text { and }(d))\end{array}$} \\
\hline (d) Millers with monthly output $\geq 50$ & $6.82($ samba type) & \\
\hline (e) Millers with monthly output $\leq 50$ & 8.83( nadu type) & \multirow{2}{*}{$\begin{array}{l}1.30 \\
(\text { Between }(\mathrm{e}) \text { and }(\mathrm{f}))\end{array}$} \\
\hline (f) Millers with monthly output $\geq 50$ & $6.99($ nadu type) & \\
\hline
\end{tabular}

Further, the result imply that the technological progressiveness of millers have not led to higher marketing margins. The mean average marketing margin does not differ significantly between millers who are technologically more progressive and millers with primary technology (Table 7).

Time series data of paddy producer price, retail price of rice and wholesale price of rice in 1991 to 2011 in real terms were used to test the hypothesis that there is an increasing trend in marketing margin due to the presence of market power. The results of the analysis are presented in Table 8.

\footnotetext{
${ }^{6} \mathrm{Samba}$ is a short grain rice type which obtains higher implicit price than Nadu which is a long-bold grain rice type.
} 
Table 7: Gross Marketing Margin and Availability of Modern Machinery

\begin{tabular}{|c|c|c|}
\hline Category & $\begin{array}{l}\text { Mean Gross } \\
\text { Marketing Margin }\end{array}$ & Unpaired t Statistic \\
\hline (a) Millers without dryers & 7.25 & \multirow{2}{*}{$\begin{array}{l}-0.48 \\
(\text { Between (a) and (b)) }\end{array}$} \\
\hline (b) Millers with dryers & 7.79 & \\
\hline (c) Millers without elevators & 7.42 & \multirow{2}{*}{$\begin{array}{l}-0.21 \\
(\text { Between }(c) \text { and }(d))\end{array}$} \\
\hline (d) Millers with elevators & 7.67 & \\
\hline (e) Millers without color separators & 7.41 & \multirow{2}{*}{$\begin{array}{l}-0.64 \\
(\text { Between (e) and (f)) }\end{array}$} \\
\hline (f) Millers with color separators & 8.73 & \\
\hline
\end{tabular}

Table 8: Regression Estimates for Marketing Margins

\begin{tabular}{|c|c|c|c|c|c|}
\hline Dependent Variable & $\begin{array}{l}\text { Constant } \\
\text { (a) }\end{array}$ & $\begin{array}{l}\text { Coefficient } \\
\text { (b) }\end{array}$ & $\begin{array}{l}\mathrm{t} \text { Ratio of } \\
\text { Coefficient }\end{array}$ & $\begin{array}{l}\mathrm{p} \\
\text { Value }\end{array}$ & $\begin{array}{l}\text { Adjusted } \\
\mathrm{R}^{2}\end{array}$ \\
\hline $\begin{array}{l}\text { Real producer price (Rs./kg } \\
\text { of rice equivalent) }\end{array}$ & $\begin{array}{l}13.95 \\
(0.699)\end{array}$ & $\begin{array}{l}-0.168 \\
(0.056)\end{array}$ & $-3.02 * * *$ & 0.007 & 0.289 \\
\hline $\begin{array}{l}\text { Average wholesale real } \\
\text { price (Rs./kg) }\end{array}$ & $\begin{array}{l}20.369 \\
(0.761)\end{array}$ & $\begin{array}{l}-0.278 \\
(0.061)\end{array}$ & $-4.58 * * *$ & 0.000 & 0.500 \\
\hline $\begin{array}{l}\text { Average real retail } \\
\text { price (Rs./kg) }\end{array}$ & $\begin{array}{l}23.554 \\
(0.746)\end{array}$ & $\begin{array}{l}-0.362 \\
(0.059)\end{array}$ & $-6.08 * * *$ & 0.000 & 0.643 \\
\hline $\begin{array}{l}\text { Real farm gate-wholesale } \\
\text { marketing margin (Rs./kg) }\end{array}$ & $\begin{array}{l}06.420 \\
(0.317)\end{array}$ & $\begin{array}{l}-0.110 \\
(0.025)\end{array}$ & $-4.35 * * *$ & 0.000 & 0.473 \\
\hline $\begin{array}{l}\text { Real farm gate-retail } \\
\text { marketing margin (Rs./kg) }\end{array}$ & $\begin{array}{l}9.607 \\
(0.284)\end{array}$ & $\begin{array}{l}-0.194 \\
(0.023)\end{array}$ & $-8.56 * * *$ & 0.000 & 0.783 \\
\hline $\begin{array}{l}\text { Real retail-wholesale } \\
\text { marketing margin (Rs./kg) }\end{array}$ & $\begin{array}{l}3.418 \\
(0.142)\end{array}$ & $\begin{array}{l}-0.093 \\
(0.011)\end{array}$ & $-8.62 * * *$ & 0.000 & 0.788 \\
\hline
\end{tabular}

*** Significant at $1 \%$ probability level.

Standard errors are in parenthesis.

Marketing margins provide an indication of the performance of a particular industry (Tomek and Robinson, 1990). For instance, Gordon and Hazledine (1996) have argued 
and shown in their study that the form of the market power is likely to manifest in larger marketing margins than would otherwise be the case. According to the results of the regression analysis on marketing margins over time, all the marketing margins considered have negative coefficients which are statistically significant. Real farm gate -wholesale marketing margin, the real farm gate - retail marketing margin and the real retail - wholesale marketing margin have been declining over time. These results suggest contrary to the expectation that marketing margins had not been widened over time to suspect any emergence or growth of market power.

Similar conclusions have been arrived using different methodologies and datasets by the World Bank (1996), Rafeek et al. (undated), Wijesuriya and Priyadarshana (2013), Senanayake and Premaratne (2016) and Senaratne et al. (2017). According to the World Bank (1996), around 8,000 rice millers were present in the island in 1986 and the market was competitive. Rafeek et al. (undated) found that milling sectors in Ampara and Polonnaruwa were competitive and there existed a large number of millers with semi-modern mills and that the price of rice is determined by the quality of rice. Using data from two surveys Senanayake and Premaratne (2016) revealed that the profit margins accruing to almost all the players involved in the paddy/rice value chains of both Nadu and Samba varieties are not excessive when compared with the average bank lending rate of 15 percent. Wijesuriya and Priyadarshana (2013) assessed the structure, conduct and performance in the rice milling industry in Polonnaruwa and Hambantota in Sri Lanka and concluded that the rice milling industry in Polonnaruwa is slightly concentrated and Hambantota is very competitive. The major entry barriers to the industry are lack of capital, lack of experience and knowledge on milling technology, high competition and unstable output market. Senaratne et al. (2017) who did an indepth investigation on rice value chains also concluded that the rice market is competitive.

\section{SUMMARY AND CONCLUSIONS}

The purpose of this study was to analyse the structure, conduct and performance of the rice milling industry of Sri Lanka. The results of the analysis conducted to ascertain the structure of the market indicated that the top four firms in the sample occupied $6.3 \%$ of market share implying that the rice milling industry of Sri Lanka was atomistically competitive. The calculated $\mathrm{H}$ index of 30 also suggested that the market was competitive. The results of the Hedonic price analysis indicated that consumer was indifferent between brands in the particular market segment and that none of the established brands had a significant effect on rice prices: hence an anti-competitive behavior is not evident. There is no statistically significant difference among the technical efficiencies of large scale millers who possess modern machinery and the rest. It was found that the marketing margins have been declining over time and millers with 
superior milling equipment do not enjoy excessive margins. Accordingly, it is concluded that there is no scientific evidence to ascertain any anti-competitive behavior in the rice milling industry of Sri Lanka.

\section{IMPLICATIONS FOR FURTHER RESEARCH}

The results of this study should be interpreted with caution due to two main reasons. Firstly, in the absence of an island-wide dataset for a recent year, it used an existing dataset gathered from a postal survey. It is quite possible that the largest millers are among the non-respondents and if this is the case, the concentration ratios and $\mathrm{H}$-indices computed in this study could have underestimated the concentration in the industry. Secondly, the absence of anticompetitive behavior revealed by the results of the study cannot be extended to the monopsony power of the rice millers as adequate research has not been carried out on the interface between rice millers and paddy farmers. Therefore, it is suggested to conduct an island-wide survey among the rice millers of the country to gather necessary data to compute the concentration ratios and $\mathrm{H}$-indices as well as the degrees of monopoly power and monopsony power of the rice millers preferably using the econometric models of the New Empirical Industrial Organisation. The dataset can also be utilised to estimate technical efficiency in rice milling and implicit prices paid for different quality attributes of rice produced by the millers. Future research should also be directed to evaluate the extent to which state interventions, i.e., the guaranteed price of paddy, ceiling price of rice, and government procurement influenced the organisation of the rice milling industry.

\section{REFERENCES}

Athukorala, P.C, and Kelegama S. (1998). The Political Economy of Agricultural Trade Policy: Sri Lanka in the Uruguay Round. Contemporary South Asia. (pp.7-36).

Bain, J.S. (1951). Relation of profit rate to industry concentration: American Manufacturing, 1936-1940. The Quarterly Journal of Economics, 65 (3), 293.

Bain J.S. (1959). Industrial Organization. Wiley: New York.

Banker, R .D., Charnes A., and Cooper W.W. (1984). Some models for estimating technical and scale inefficiencies in data envelopment analysis. Management Science,30(9), 1078-1092.

Central Bank, Annual Reports. (various years) Colombo, Sri Lanka.

Charnes, Abraham, Cooper W.W., and Rhodes E., (1978). Measuring the efficiency of decision making units. European Journal of Operational Research 2(6), 429-444. 
Goodwin, H. L., Holcomb R.B., and Rister M.E. (1996). Implicit price estimation of rice quality attributes for Asian-Americans. Journal of Agricultural and Applied Economics, 28(02), 291-302.

Gordon, D.V., and Hazledine T. (1996). Agriculture and Agri-Food Canada. Research Branch. Information Management Group. Modelling Farm-Retail Price Linkage For Eight Agricultural Commodities. Agriculture and Agri-Food Canada, Policy Branch. available online: http://dsp-psd.communication.gc.ca/Collection/A21-491996-1E.pdf

Gunawardana, P.J. \& Quilkey,J.J. (1987). Pricing and Marketing Policies in the Rice Sector of Sri Lanka. Upanathi 2(2): 227-279.

Gunawardana, P. J., \& Somaratne, W.G. (2000). Non-plantation agricultural economy of Sri Lanka: trends, issues and prospects. Sri Lankan Journal of Agricultural Economics. Volume 3, Number 1.Pp $15-45$.

Hector Kobbekaduwa Agrarian Research Institute.(2007).Paddy Milling Survey 2006. Available online http://dl.nsf.ac.lk/ohs/harti/21825.pdf

Indraratna, A.D.V.de S. (2009). From a closed regime to an open economy and lessons for the future. Sri Lanka Economy in Transition: Progress, Problems, and Prospects.

Institute of post-harvest technology. (2003). (as cited in Palipane, K.B. (undated) available

online http://www.goviya.lk/agrilearning/Paddy/Paddy_Research/Paddy_pdf/AM2. pdf

Karunagoda, K., Samaratunga P., Sharma R., and Weerahewa J. (2011). Sri LankaAgricultural trade policy issues. In Articulating and Mainstreaming Agricultural Trade Policy and Support Measures Edited by by Ramesh Sharma and Jamie Morrison, 245-263. Rome: Food and Agricultural Organization.

Kohls, R. L., \& Uhl, J. N. (1996). Marketing of Agricultural Products. Macmillan Publishing Company. New York.

Landes, W.M., and Posner A.R. (1981). Market power in antitrust cases. Harvard Law Review, 937-996. 
Mhlanga, S. (2010). Economic analysis of consumer based attributes for rice in Benin. A thesis submitted to McGill University in partial fulfillment of the requirements of the degree of Master of Science, Department of Agricultural Economics, McGill University.

Rafeek, M.I.M., Mahrouf A.R.M., and Samaratunga P.A. (undated). Rice Marketing System: Implication for Rice Quality Improvement and Issue of Affordability. Available online: http://agrilearning.goviya.lk/Paddy/Paddy_Research/Paddy_pdf/SE13.pdf

Schmalensee, R. (1985). Do markets differ much?. The American economic review, 75(3), 341-351.

Schmalensee, R. (1989). Inter-industry Studies of Structure and Performance. Handbook of Industrial Organization Handbook of Industrial Organization. (pp 951-1009).

Senanayake, S.M.P. and Premartne, S.P. (2016). An Analysis of the Paddy/Rice Value Chains in Sri Lanka. ASARC Working Paper 2016/04. available online: https://crawford.anu.edu.au/acde/asarc/pdf/papers/2016/WP2016_04.pdf

Senaratne, A., Thibbotuwawa, M., Hirimuthugodage, D., Wickramasinghe, K.,Manaweera, H., Premaratne, K. and Dayananda, D. (2017). Assessing Policy Options for Ensuring Food Security in Sri Lanka: A Multi-market Analysis of Rice, Fish and Dairy Products, Research Study Report, National Thematic Research Program on Food Security, National Science Foundation, Colombo.

Tomek, W. E., \& Robinson, K. L. (1990). Agricultural Product Prices, Cornell University Press. Ithaca and London.

Walisinghe, B. \& Gunaratne, L., (2012). Consumer Preferences for Quality Attributes of Rice: A Conjoint Analysis. Sri Lankan Journal of Agricultural Economics. 10, pp.19-30. DOI: http://doi.org/10.4038/sjae.v10i0.4589

Weerahewa, J.(2004). Imapct of Trade Liberalization and Market Reforms on the Paddy/Rice Sector in Sri Lanka. Washington: Market, Trade, and Institutions Division, International Food Policy Research Institute.

Weerahewa, J., Korale Gedara, P., Kanthilanka, H., (2016). The Evolution of Food Policy in Sri Lanka: 1948-2017. Reference Module in Food Sciences. Elsevier, pp. 1-19. doi: http://dx.doi.org/10.1016/B978-0-08-100596-5.21179-7 
Wijesuriya, W.A.N. and Priyadarshana W.H.D. (2013), Structure, Conduct and Performance of Rice Milling Industry in Polonnaruwa and Hambantota Districts of Sri Lanka. Hector Kobbekaduwa Agrarian Research and Training Institute (HARTI), Colombo, Sri Lanka.

World Bank (1996), Sri Lanka-Non plantation crop sector policy alternative. Report No. 14564. World Bank.

Yoshimura H., Perera, M. P and Gunawardana, P.J. (1975). Some aspects of paddy and rice marketing in Sri Lanka: Based on a study done in four selected districts. Colombo: Agrarian Research and Training Institute. 